\title{
Orexin Receptor-1 in the Locus Coeruleus Plays an Important Role in Cue-Dependent Fear Memory Consolidation
}

\author{
Shingo Soya, ${ }^{1}$ Hirotaka Shoji, ${ }^{2}$ Emi Hasegawa, ${ }^{1}$ Mari Hondo, ${ }^{1}$ Tsuyoshi Miyakawa, ${ }^{2}$ Masashi Yanagisawa, ${ }^{3}$ \\ Michihiro Mieda, ${ }^{1}$ and Takeshi Sakurai ${ }^{1}$ \\ ${ }^{1}$ Department of Molecular Neuroscience and Integrative Physiology, Faculty of Medicine, Kanazawa University, Kanazawa, Ishikawa 920-8640, Japan, \\ ${ }^{2}$ Division of Systems Medical Science, Institute for Comprehensive Medical Science, Fujita Health University, Toyoake, Aichi 407-1192, Japan, and \\ ${ }^{3}$ International Institute for Integrative Sleep Medicine, University of Tsukuba, Tsukuba 305-8575, Japan
}

The noradrenergic (NA) projections arising from the locus ceruleus (LC) to the amygdala and bed nucleus of the stria terminalis have been implicated in the formation of emotional memory. Since NA neurons in the LC (LC-NA neurons) abundantly express orexin receptor-1 (OX1R) and receive prominent innervation by orexin-producing neurons, we hypothesized that an OX1R-mediated pathway is involved in the physiological fear learning process via regulation of LC-NA neurons. To evaluate this hypothesis, we examined the phenotype of $O x 1 r^{-1-}$ mice in the classic cued and contextual fear-conditioning test. We found that $O x 1 r^{-1-}$ mice showed impaired freezing responses in both cued and contextual fear-conditioning paradigms. In contrast, $O x 2 r^{-/-}$mice showed normal freezing behavior in the cued fear-conditioning test, while they exhibited shorter freezing time in the contextual fear-conditioning test. Double immunolabeling of Fos and tyrosine hydroxylase showed that double-positive LC-NA neurons after test sessions of both cued and contextual stimuli were significantly fewer in $O x 1 r^{-/}$mice. AAV-mediated expression of OX1R in LC-NA neurons in $O x 1 r^{-/-}$mice restored the freezing behavior to the auditory cue to a comparable level to that in wild-type mice in the test session. Decreased freezing time during the contextual fear test was not affected by restoring OX1R expression in LC-NA neurons. These observations support the hypothesis that the orexin system modulates the formation and expression of fear memory via OX1R in multiple pathways. Especially, OX1R in LC-NA neurons plays an important role in cue-dependent fear memory formation and/or retrieval.

\section{Introduction}

Orexins (Sakurai et al., 1998) are implicated in regulation of sleep/wakefulness, energy homeostasis, and the reward system (Sakurai, 2007; Sakurai and Mieda, 2011). Orexin-immunoreactive fibers are observed in almost the entire neuraxis (Peyron et al., 1998; Date et al., 1999; Nambu et al., 1999), with especially dense fibers in monoaminergic nuclei in the brainstem (Date et al., 1999; Nambu et al., 1999; Peyron et al., 2000). The distribution of the two orexin receptors is consistent with these projection sites (Marcus et al., 2001).

It has been thought that orexin-2 receptor (OX2R) plays a pivotal role in sleep-wake regulation (Hondo et al., 2010; Sakurai and Mieda, 2011). Metabolic and feeding regulation by orexins is also suggested to be regulated through an OX2R-mediated path-

\footnotetext{
Received March 13, 2013; revised July 18, 2013; accepted Aug. 6, 2013.

Author contributions: T.S. designed research;S.S., H.S., M.H., and T.S. performed research; E.H., T.M., M.Y., M.M., and T.S. contributed unpublished reagents/analytic tools; S.S. and T.S. analyzed data; S.S. and T.S. wrote the paper.

This work was funded primarily by the government of Japan through its "Funding Program for Next Generation of World-leading Researchers" (grant to T.S.). PRSx8 was provided by Dr. Kwang-s0o Kim. We thank Dr. Wendy Gray for reading this manuscript.

Correspondence should be addressed to Dr. Takeshi Sakurai, Department of Molecular Neuroscience and Integrative Physiology, Faculty of Medicine, Kanazawa University, Kanazawa, Ishikawa 920-8640, Japan. E-mail: tsakurai@med.kanazawa-u.ac.jp or takeshi.sakurai@gmail.com.

DOI:10.1523/JNEUROSCI.1130-13.2013

Copyright $\odot 2013$ the authors $\quad 0270-6474 / 13 / 3314549-09 \$ 15.00 / 0$
}

way (Funato et al., 2009). However, very limited information is available regarding the physiological role of the orexin-1 receptor (OX1R).

OX1R is abundantly expressed in the locus ceruleus (LC), which plays important roles in many functions via its widespread projections (Bailey et al., 2000; McGaugh and Roozendaal, 2002). The LC contains tyrosine hydroxylase $(\mathrm{TH})$-positive noradrenergic (NA) neurons. Because orexin neurons send rich projections to the LC, and OX1R is expressed in Vmat2-positive neurons in the LC (Mieda et al., 2011), the physiological function of OX1R might be closely related to the function of NA neurons in the LC (LC-NA neurons). Consistently, orexin potently excited LC-NA neurons (van den Pol et al., 2002).

There is much evidence suggesting the importance of the NA system in emotional memory formation. Conditioned fear stress caused a robust increase in the firing rate of NA neurons (Chen and Sara, 2007) and induced Fos expression in the LC (Ishida et al., 2002). LC-NA neurons project to the lateral amygdala (LA), an important structure for emotional memory (Bush et al., 2010). These observations suggest that NA input from the LC to the LA is one of the key factors in fear memory formation.

Orexin neurons receive input from the limbic system (Winsky-Sommerer et al., 2004; Sakurai et al., 2005; Yoshida et al., 2006). These observations raise the possibility that orexin neurons may be activated by emotional information transmitted 
from the amygdala, and in turn send excitatory output to the LC, and this connection plays an important role in modulating emotional memory.

We found here that $\mathrm{Oxlr}^{-/-}$mice showed decreased freezing behavior to both cued and contextual stimuli during both the conditioning and test periods, suggesting that OX1R is involved in evoking fear-related behavior. In contrast, $\mathrm{O} \times 2 \mathrm{r}^{-1-}$ mice responded normally with freezing behavior in the cued fearconditioning test. We also found that Fos expression in LC-NA neurons after exposure to the fearful context was significantly lower in $O x 1 r^{-/-}$mice than in wild-type mice. Importantly, we found that freezing behavior recovered to a level comparable to that in wild-type mice in the test period of cued fear conditioning when OX1R expression in LC-NA neurons was restored, suggesting that OX1R-mediated regulation of LC-NA neurons plays a significant role in the acquisition and consolidation of cuedependent fear memory.

\section{Materials and Methods}

Animals. All experimental procedures were approved by the Animal Experiment and Use Committee of Kanazawa University (AP-111947), and were thus in accordance with National Institutes of Health guidelines. We used $O x 1 r^{-1-}$ mice in which the Ox1r-coding region in exon 1 of the OxIr gene is disrupted by inserting a tau-LacZ cassette (Hondo et al., 2010). Ox1r $r^{-1-}$ mice used in the experiments were obtained from the mating of heterozygous $O \times 1 r^{+/-}$mice. $O \times 2 r^{-1-}$ mice were previously reported (Willie et al., 2003). Exon 1 of the $O x 2 r$ gene was replaced in-frame with the nlac $Z$ cassette. $O x 2 r^{-/-}$mice used in the experiments were obtained from the mating of heterozygous $\mathrm{O} \times 2 \mathrm{r}^{+/-}$mice. Genotyping these mice was done by PCRs with tail DNA according to the method described previously (Willie et al., 2003). These mice were backcrossed to wild-type C57BL/6J mice for $>10$ generations. Their littermates of each genotype were used as wild-type control. Mice were maintained under a strict $12 \mathrm{~h}$ light/dark cycle in a temperature- and humidity-controlled room and fed ad libitum.

Behavioral experiments. All experiments were performed during the light phase (13:00-16:00) using male 12- to 14-week-old mice. Before the experiments, these mice were isolated for 2 weeks. The experimenters were blinded to the genotypes until all data had been gathered and analyzed. Behavioral experiments in this study were basically performed according to modifications of previously described protocols (Miyakawa et al., 2003). The behavior of mice was recorded using a charge coupled device video camera and analyzed with a video-tracking system CompACT VAS version 3.0x (Muromachi Kikai). For the cued fearconditioning test, mice were placed in a conditioning chamber $(15 \times$ $12 \times 13 \mathrm{~cm}$, acrylic walls with a gridded floor and bright lighting) for $90 \mathrm{~s}$ before giving a conditioned stimulus (CS), a $2900 \mathrm{~Hz}, 80 \mathrm{~dB}$ tone that lasted $30 \mathrm{~s}$ immediately, followed by the presentation of an unconditioned stimulus (US), a mild foot shock of $0.3 \mathrm{~mA}$ for $2 \mathrm{~s}$, on the training day. Five consecutive trials of training were performed (see Fig. 1A). After an additional stay for $90 \mathrm{~s}$ in the chamber, the mouse was returned to its home cage. Mice were tested $24 \mathrm{~h}$ after the training. Cued fear test was conducted in a chamber with a different context $(13 \times 20 \times 11 \mathrm{~cm}$, a plastic cage surrounded with a white screen and bright lighting). Freezing behavior was scored during the testing session. Freezing behavior is defined as the complete absence of any movement except for respiration and heartbeat. Freezing behavior is measured by an automated scoring system (Muromachi Kikai), which recognizes complete absence of movement lasting for longer than $2 \mathrm{~s}$ as freezing. Testing was performed with the same procedure as in the conditioning period, but without application of US (Fig. 1A).

For the contextual fear-conditioning test, mice were placed in the conditioning chamber for $90 \mathrm{~s}$ before giving a US, a mild foot shock of 0.3 $\mathrm{mA}$ for $2 \mathrm{~s}$, on the training day. Five sequential foot shocks at $90 \mathrm{~s}$ intervals were applied. The mice were tested $24 \mathrm{~h}$ after the conditioning. They were put in the same conditioning chamber for $5 \mathrm{~min}$ without presentation of CS (see Fig. 2A). We used different mice for the cued test and contextual test. Data are presented as mean \pm SEM. The apparatus was cleaned with $30 \%$ ethanol solution, and then with water and dried after each trial to eliminate possible odor cues left by previous subjects.

To measure the ultrasonic vocalizations of mice, we used an ultrasonic vocalization (USV) analyzer (Muromachi Kikai), following the manufacturer's instructions.

Construction of recombinant adeno-associated virus vectors. The common structure of the adeno-associated virus (AAV)-2 ITR-containing plasmids used in this study is ITR-promoter-cDNA encoding a proteinWPRE-poly (A) ${ }^{+}$signal-ITR. cDNA encoding rat OxIr fused with EYFP at the $\mathrm{C}$ terminal was inserted downstream of the PRSx8 promoter (AAV-PRSx8-OX1R-EYFP; see Fig. 4A) (Hwang et al., 2001). We used AAV with PRSx8 promoter carrying ChR2 (NA-ChR2) for the control group (AAV-PRSX8-ChR2-EYFP; Fig. 4A), because ChR2 has a similar seven transmembrane structure to that of OX1R. AAV-2 vectors with a mutant form of the cap gene (Zhong et al., 2008) were produced using a triple-transfection, helper-free method, and purified as described previously (Sasaki et al., 2011). In brief, 293A cells (Invitrogen), cultured in 10 $100 \times 20 \mathrm{~mm}$ cell culture dishes per viral vector, were transfected with pHelper (Stratagene), pACG-2-Y730F (containing a mutant form of the cap gene of AAV2, provided by Dr. Arun Srivastava of the University of Florida), and $p A A V-P R S x 8-O X 1 R-E Y F P$ or $p A A V-P R S x 8-C h R 2-E Y F P$, using a standard calcium phosphate method. Three days later, the cells were collected, pelleted, and resuspended in freezing buffer ( $10 \mathrm{ml}$ of 0.15 $\mathrm{M} \mathrm{NaCl}, 50 \mathrm{~mm}$ Tris, $\mathrm{pH}$ 8.0). After two freeze-thaw cycles and subsequent centrifugation, each lysate was treated with DNase I $(40 \mu \mathrm{g} / \mathrm{ml})$ and RNase A (40 $\mu \mathrm{g} / \mathrm{ml}$ ) and then with deoxycholic acid (Sigma; 0.5\%), followed by filtration. Each cleared lysate was mixed with $1.5 \mathrm{ml}$ heparinagarose suspension (Sigma) equilibrated with freezing buffer, incubated with gentle rotation for $60 \mathrm{~min}$ at $4^{\circ} \mathrm{C}$, and loaded onto a Bio-Spin Column 100 (Bio-Rad). Each column was washed three times with $2 \mathrm{ml}$ freezing buffer, and viruses were eluted with $3 \mathrm{ml}$ elution buffer $(0.5 \mathrm{M}$ $\mathrm{NaCl}, 50 \mathrm{~mm}$ Tris, $\mathrm{pH}$ 8.0). Each virus preparation was dialyzed against $1 \times$ PBS using Slide-A-Lyzer Dialysis Cassettes (Pierce) and concentrated using Concentration Solution (Pierce). The final purified viruses were stored at $-80^{\circ} \mathrm{C}$. A detailed description and characterization of these viruses will also be published (E. Hasegawa, T. Sakurai, and M. Mieda., unpublished results). The titers of recombinant AAV vectors were as follows: AAV-PRSx8-ChR2-EYFP; $5.0 \times 10^{12}$, AAV-PRSx8-OX1REYFP; $8.4 \times 10^{11}$ genome copies $/ \mathrm{ml}$.

Virus injection. Ox1r ${ }^{-/-}$mice (12 weeks old) were anesthetized with sodium pentobarbital (Nembutal $50-60 \mathrm{mg} / \mathrm{kg}$, i.p.) and positioned in a stereotaxic frame (David Kopf Instruments). After drilling into the skull of each mouse at sites (anteroposterior, $-5.4 \mathrm{~mm}$; mediolateral, \pm 0.9 $\mathrm{mm}$; dorsoventral, $3.7 \mathrm{~mm}$ ), a Hamilton needle syringe (33 gauge) was placed in each site, and $1 \mu \mathrm{l}$ of purified virus was delivered over a $20 \mathrm{~min}$ period. At $14 \mathrm{~d}$ after injection, mice were subjected to behavioral experiments, and then killed and brain samples were examined by immunohistochemical staining. Behavioral data were only included if OX1R was precisely targeted to the LC-NA neurons.

Fos immunohistochemistry. Mice were deeply anesthetized with sodium pentobarbital and then fixed by intracardiac perfusion with $4 \%$ paraformaldehyde $90 \mathrm{~min}$ after cued or contextual fear tests. Then, the brain was postfixed for $24 \mathrm{~h}$ in the same fixative and cryoprotected by immersion in $30 \%$ sucrose for $2 \mathrm{~d}$. Brain sections of $30 \mu \mathrm{m}$ thickness were cut with a cryostat. Sections were washed and blocked with $0.1 \mathrm{M}$ PBS containing $0.25 \%$ Triton X-100 plus $3 \%$ bovine serum albumin (BSA). Then, slices were incubated with the designated primary antibodies in PBS overnight at $4^{\circ} \mathrm{C}$. Antibodies used in this study were rabbit polyclonal antibody against $c$-Fos (1:5000, Ab-5; Millipore), mouse polyclonal antibody against tyrosine hydroxylase (TH) (1:2500, F-11; Santa Cruz Biotechnology), and goat antibody against green fluorescent protein (GFP; 1:1000; Molecular Probe). Then, slices were washed with PBS three times, followed by incubation with the designated secondary antibodies in PBS for $2.5 \mathrm{~h}$. Secondary antibodies used in this study were Alexa 594-conjugated donkey anti-rabbit IgG, Alexa 594-conjugated donkey anti-mouse IgG, Alexa 488-conjugated donkey anti-mouse IgG, and Alexa 488-conjugated donkey anti-rabbit IgG (1:1000; Invitrogen). Slices were washed three times in PBS, mounted on subbed slides, air 


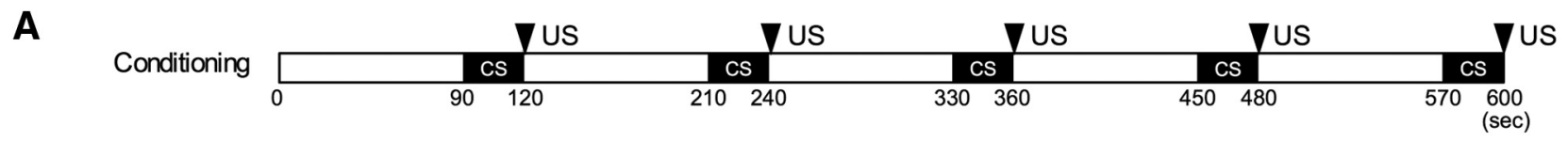

\begin{tabular}{|c|c|c|c|c|c|}
\hline Test & CS & CS & CS & $\overline{C S}$ & CS \\
\hline & 120 & $210 \quad 240$ & $330 \quad 360$ & $450 \quad 480$ & $570 \quad 600$ \\
\hline
\end{tabular}
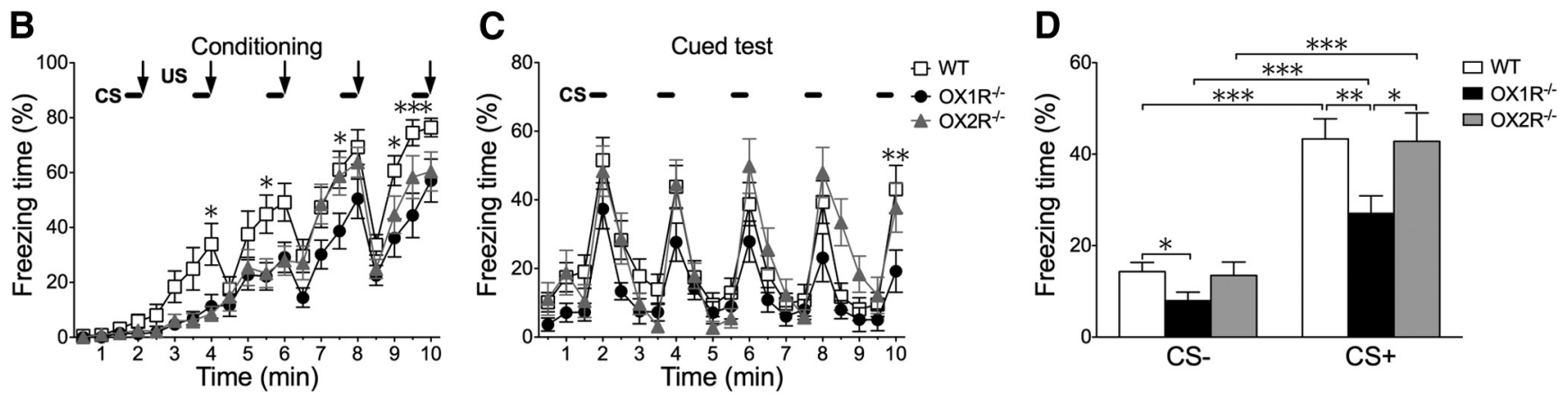

Figure 1. $0 \times 1 r^{-/-}$mice showed decreased freezing behavior in cued fear-conditioning tests. Wild-type (WT; littermates of $0 \times 1 r^{-/-}$mice) $(n=15), 0 \times 1 r^{-/-}$mice $(n=16)$ and $0 \times 2 r^{-/-}$mice $(n=15)$ were subjected to a cued fear-conditioning test. A, Schematic drawing of protocol for cued fear-conditioning test. Timing of CS and US (shown by triangles) presentation is shown. For the cued test period, mice were tested in a new cage different from those used for conditioning, and the same auditory cue (CS) was applied without electric shocks (US). B, Freezing time was counted in every $30 \mathrm{~s} \mathrm{time} \mathrm{window} \mathrm{and} \mathrm{plotted} \mathrm{over} \mathrm{time.} \mathrm{There} \mathrm{was} \mathrm{a} \mathrm{significant} \mathrm{difference} \mathrm{between} 0 \times 1 r^{-/-}$and WT mice during the conditioning session. No statistically significant difference was found between WT and $0 \times 2 r^{-1-}$ mice. Freezing time during $30 \mathrm{~s}$ epochs in the test session was counted before (CS - ) and during presentation of the cue (CS + ). $C$, Freezing time counted in every $30 \mathrm{~s}$ window, plotted over time. $D$, Graphic representation of total time during test session itemized for CS - and CS + periods. Data are shown as mean \pm SEM. There was a significant difference during both the presentation of CS and the period of $C S-.{ }^{*} p<0.05,{ }^{* *} p<0.01$, and ${ }^{* * *} p<0.001$.

dried, and coverslipped using FluorSave Reagent (Calbiochem). The numbers of Fos-positive and Fos-negative NA neurons were counted in every coronal section throughout the LC by a single examiner who was blinded to the genotype of mice, using images taken with a confocal laser-scanning microscope FV10i (Olympus). Cells were counted on both sides of the brain in four consecutive $30 \mu \mathrm{m}$ sections. Activity of NA neurons was scored as the percentage of double-labeled cells per animal.

To assess amygdala activity, we detected for Zif268 immunoreactivity in the lateral region of the amygdala. Coronal sections of brains were incubated for $35 \mathrm{~min}$ in $0.6 \%$ hydrogen peroxide to eliminate endogenous peroxide activity. Sections were rinsed in PBS and incubated for 30 min in Tris-buffered saline (TBS) containing 3\% goat serum and $0.25 \%$ Triton X-100. Thereafter, sections were incubated overnight with rabbit anti-Egr-1 (Zif268) antibody (C-19; Santa Cruz Biotechnology) in TBS containing 3\% BSA and $0.25 \%$ Triton X-100. The primary antibody was localized with the avidin-biotin system (Vector Laboratories). Zif268-positive neurons were counted in coronal sections throughout the LA region by a single examiner who was blinded to the treatment conditions, using a Keyence BZ-9000 microscope. The region of interest was designated as previously described (DíazMataix et al., 2013). Cells were counted on both sides of the brain in consecutive $40 \mu \mathrm{m}$ sections throughout the LA using Image $1.46 \mathrm{r}$ software (http://rsbweb.nih.gov/ij/).

Statistical analysis. Data were expressed as mean \pm SEM. Two-way ANOVA followed by Bonferroni correction as a post hoc test or Student's $t$ test using GraphPad Prism 5.0b was used for comparison among the various treatment groups. Differences were considered significant at $p<$ 0.05 .

\section{Results}

Differential roles of OX1R and OX2R in cued and contextual fear conditioning

To evaluate the possibility that OX1R-mediated pathways are involved in presentation of fear-related behavior and/or fear memory formation/acquisition, we tested $O \times 1 r^{-1-}$ mice and $O \times 2 r^{-1-}$ mice in cued and contextual fear-conditioning tests. Schematic representations of the training and testing protocols of these fearconditioning paradigms are shown in Figures $1 A$ and $2 A$.
$O \times 1 r^{-/-}$mice displayed a significant decrease of evoked freezing behavior during both cued and contextual fear tests compared with wild-type littermates, while $O \times 2 r^{-1-}$ mice showed a decreased freezing response only in the contextual test (Figs. 1D, $2 D)$. In the cued fear conditioning, these mice already showed significant impairment of freezing behavior in the conditioning period $\left(F_{(1,29)}=9.50 ; p=0.0045\right)$, while $O \times 2 r^{-/-}$mice also showed a tendency for a shorter freezing time, although it did not reach significance $\left(F_{(1,28)}=4.00 ; p=0.0552\right.$; Fig. $\left.1 B\right)$. In the conditioning session, although all groups showed a gradual increase in freezing time in response to CS paired with US, Ox1r ${ }^{-1-}$ mice showed a significantly shorter freezing time in each epoch. In the cued test period, $O \times 1 r^{-/-}$mice also showed a significantly shorter freezing time in the periods of both presence and absence of CS compared with wild-type mice $\left(F_{(1,29)}=7.88, p=0.0088\right.$; Fig. $1 C, D)$.

The intensity of the freezing response shown after shock delivery is also related to the level of sensory perception of mice. We examined the sensory perception function of $O x 1 r^{-1-}$ and control mice by measuring USVs of these mice against various intensity of foot shock (US) and found that the threshold intensity of US to evoke USVs was not different between genotypes (WT $0.07 \pm 0.0065 \mathrm{~mA}, O x 1 r^{-/-} 0.06 \pm 0.0067 \mathrm{~mA}, n=8$ each, $p=$ $0.6004)$. The frequency and amplitude of USVs evoked by the foot shock were also not different between genotypes (WT $58.6 \pm$ $3.34 \mathrm{~dB}, 24433.6 \pm 3040 \mathrm{~Hz} ; O x 1 r^{-l-} 59.0 \pm 2.66 \mathrm{~dB}, 25570.3 \pm$ $2460 \mathrm{~Hz}, p=0.9151$ and 0.7756 , respectively). This result excludes the possibility that $O x 1 r^{-1-}$ mice exhibit a decreased response to foot shock due to decreased sensitivity to US.

In the contextual fear-conditioning test, there was a significant difference between $O x 1 r^{-1-}(n=17)$ and wild-type $(n=19)$ mice during the conditioning period $\left(F_{(1,34)}=9.09 ; p=0.0048\right)$. Also, there was a significant difference between $O \times 2 r^{-1-}$ mice $(n=15)$ and wild-type mice $\left(F_{(1,30)}=4.30 ; p=0.0467\right.$; Fig. $\left.2 B\right)$. During the test session, there was significant impairment of freez- 

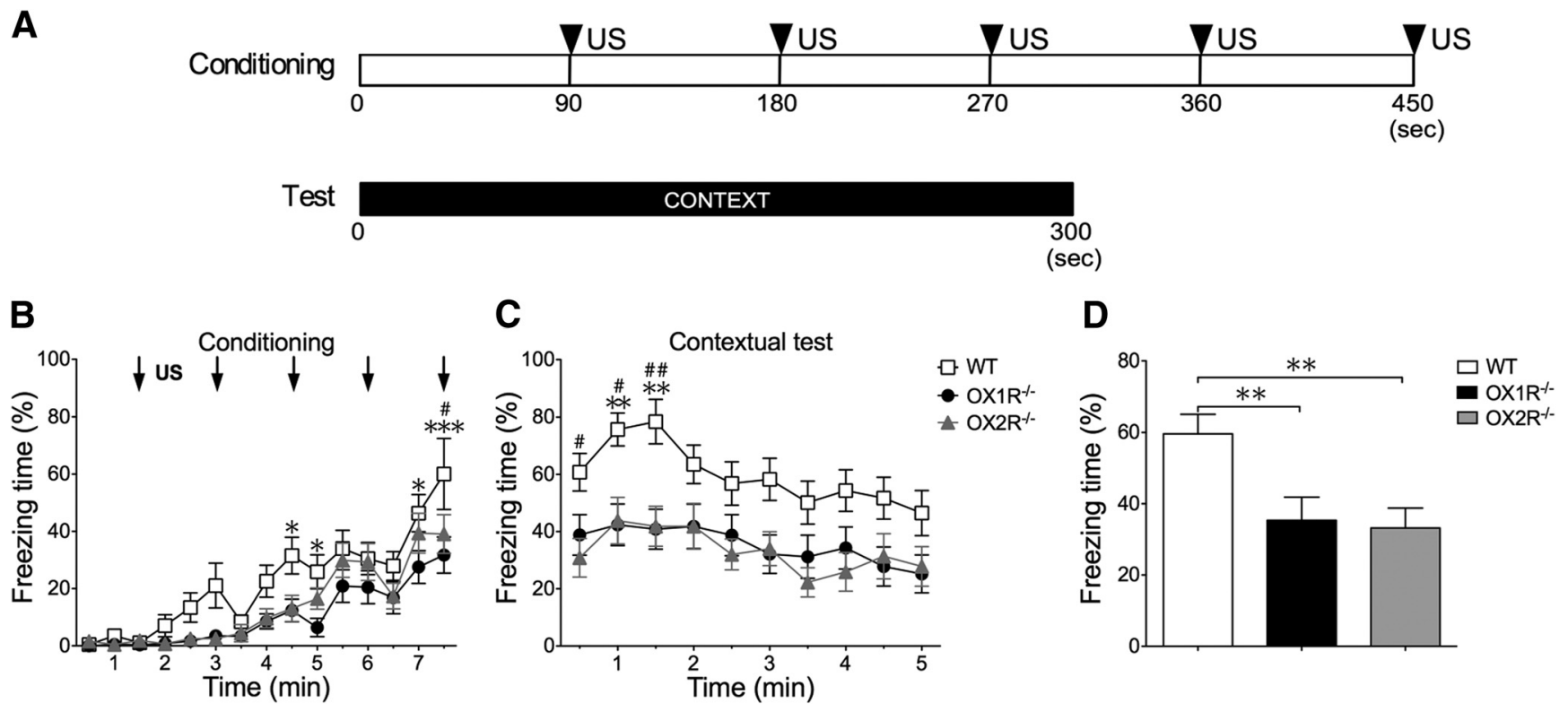

Figure 2. Impaired freezing behavior in $0 \times 1 r^{-/-}$mice and $0 \times 2 r^{-/-}$mice in contextual fear-conditioning test. Contextual fear conditioning was performed to examine the ability of $0 \times 1 r^{-/-}$ and $0 \times 2 r^{-1-}$ mice to learn and remember the context in which an electric shock was presented. $A$, Protocol for contextual fear-conditioning test. For the contextual test, mice were tested in the conditioning cage and stayed there for 300 s. B, C, Freezing time counted in every 30 s epoch, plotted over time. $0 \times 1 r^{-/-}(n=17)$ and $0 \times 2 r^{-/-}(n=15)$ mice showed significant impairment of freezing time compared with wild-type (WT; $n=19)$ mice during both the conditioning and test periods. Data are shown as mean \pm SEM. ${ }^{*} p<0.05,{ }^{* *} p<0.01$, and ${ }^{* * *} p<0.001\left(0 \times 1 r^{-/-}\right.$ mice vs WT), \#p $<0.05$ and \#\#p $<0.01$ ( $0 \times 2 r^{-1-}$ mice vs WT). $D$, Graphic representation of total time during test session. ${ }^{* *} p=0.01$.

ing duration in both $O x 1 r^{-/-}\left(F_{(1,34)}=7.92 ; p=0.0081\right)$ and $O \times 2 r^{-1-}$ mice $\left(F_{(1,30)}=11.25 ; p=0.0022\right)$ compared with wildtype mice (Fig. 2C). The degree of impairment in $\mathrm{OxIr}^{-1-}$ mice compared with wild-type mice was larger in the test session than in the conditioning period. These results suggest that the decrease of freezing behavior in $O x 1 r^{-1-}$ mice is due to abnormalities both in the mechanisms that evoke fear-related behavior itself and in the formation of fear memory. While Oxlr ${ }^{-1-}$ mice showed decreased freezing behavior in both the cued and contextual fearconditioning tests, $O \times 2 r^{-1-}$ mice showed impairment only in the contextual fear-conditioning test (Figs. 1, 2). This suggests that $\mathrm{OX} 1 \mathrm{R}$ is involved in both cued fear conditioning and contextual fear conditioning, while OX2R plays a role only in contextual fear conditioning.

\section{Impaired response of LC-NA neurons of $O x \mathrm{Ir}^{-/-}$mice after exposure to fearful situations}

Since OX1R is most abundantly expressed in the LC, we examined the activity of NA neurons in the LC, in which the largest source of NA neurons in the brain is located. In this experiment, we examined Fos expression in LC-NA neurons after each session of cued and contextual fear paradigms (Fig. 3). Mice were killed 90 min after the conditioning or test and their brains were subjected to analysis. Double-labeling immunofluorescence analysis with $\mathrm{TH}$ and Fos antibodies revealed that the number of Fospositive LC-NA neurons was very low and comparable in both genotypes in the naive condition (Fig. $3 B$ ). After the cued or contextual conditioning, the number was increased in both genotypes. However, $\mathrm{O} \times 1 r^{-1-}$ mice showed a significantly lower number of double-labeled cells in the LC compared with wildtype after both cued and contextual conditioning (Fig. 3C,E). The number of double-positive cells was also increased after the test sessions compared with basal conditions, but $O x 1 r^{-/-}$mice again showed a lower response compared with wild-type (Fig.
$3 D, F)$. These observations suggest that an OX1R-mediated pathway activates LC-NA neurons in emotionally relevant situations.

\section{Restoration of OX1R expression in LC-NA neurons normalized cued fear behavior in $\mathrm{OxIr}^{-/-}$mice} We found that $O x 1 r^{-1-}$ mice showed lower activity of LC-NA neurons after cued or contextual fear-conditioning and tests (Fig. 3). This suggests that OX1R-mediated activation of LC might play a role in fear memory or fear response. We next examined whether LC-NA neuron-specific restoration of OX1R expression in the LC could affect freezing behavior.

To express OX1R specifically in NA neurons in the LC, we used an AAV vector with the PRSx8 promoter, which directs expression of designated genes specifically in NA neurons. To examine the specific expression in NA neurons, we confirmed the injection sites and expression of OX1R with double-labeling immunofluorescence analysis with anti-TH and anti-GFP antibodies. GFP was specifically observed in TH-positive cells (70.43 \pm $15.62 \%$ of GFP-positive neurons were $\mathrm{TH}$ positive, $N=29$ ) in the LC (Fig. $4 B$ ). We only included the behavioral data if the injection was achieved precisely in the LC bilaterally and $>10 \%$ of TH-positive cells expressed GFP.

For the cued fear-conditioning test, we found that $O x 1 r^{-/-}$ mice with LC-NA neuron-specific expression of OX1R (KOOX1R group) did not show any difference in freezing time in the conditioning session in the presence or absence of CS, compared with the control group (Ox1r $r^{-1-}$ mice with expression of ChR2 in LC-NA neurons, KO-ChR2 group) $\left(F_{(1,13)}=0.09, p=0.7636\right.$; Fig. $4 C$ ). However, the KO-OX1R group showed freezing behavior with a level comparable to that in wild-type controls in the test session $\left(F_{(1,13)}=1.52 ; p=0.2394\right.$; Fig. $\left.4 D\right)$. Although both groups showed a significant increase of freezing times in response to $\mathrm{CS}$ presentation, the $\mathrm{KO}-\mathrm{OX} 1 \mathrm{R}$ group showed an increase of freezing time in the test period to a level comparable to that in 
A

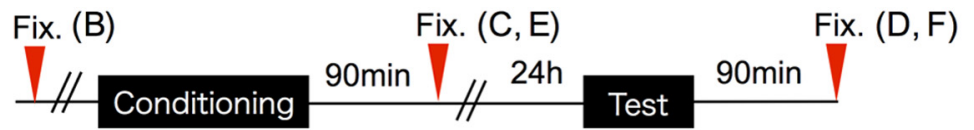

B

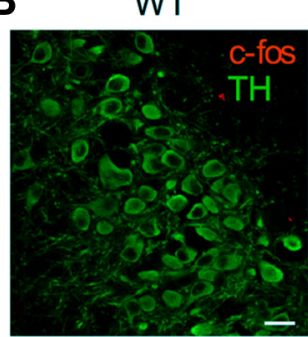

C
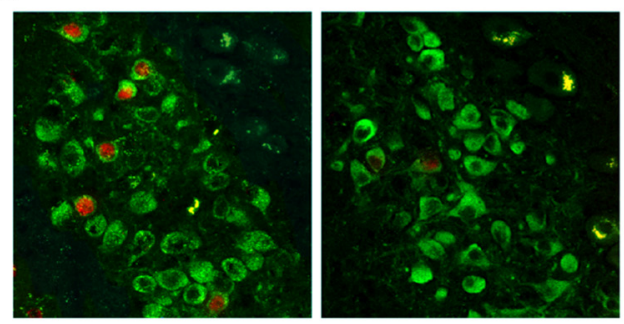

D
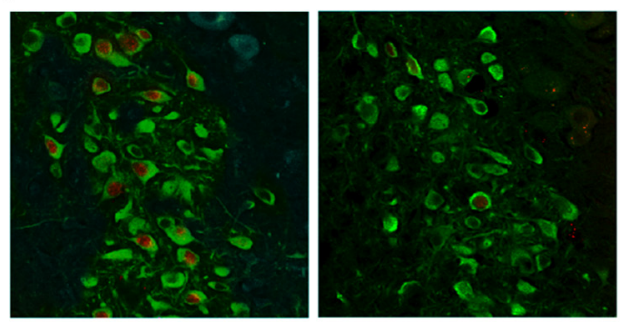

$\mathbf{E}$
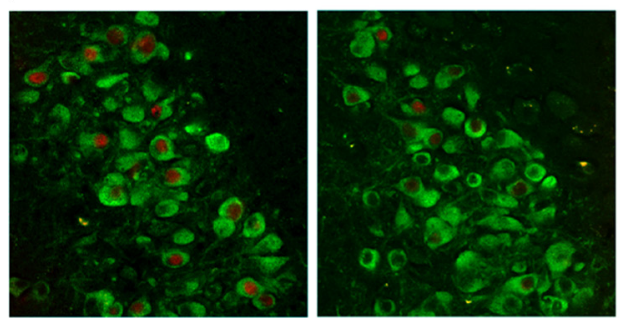

$\mathbf{F}$
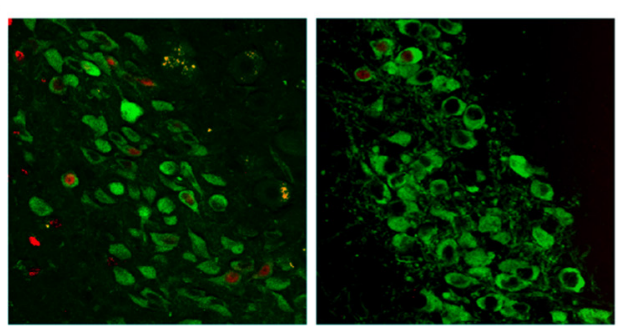
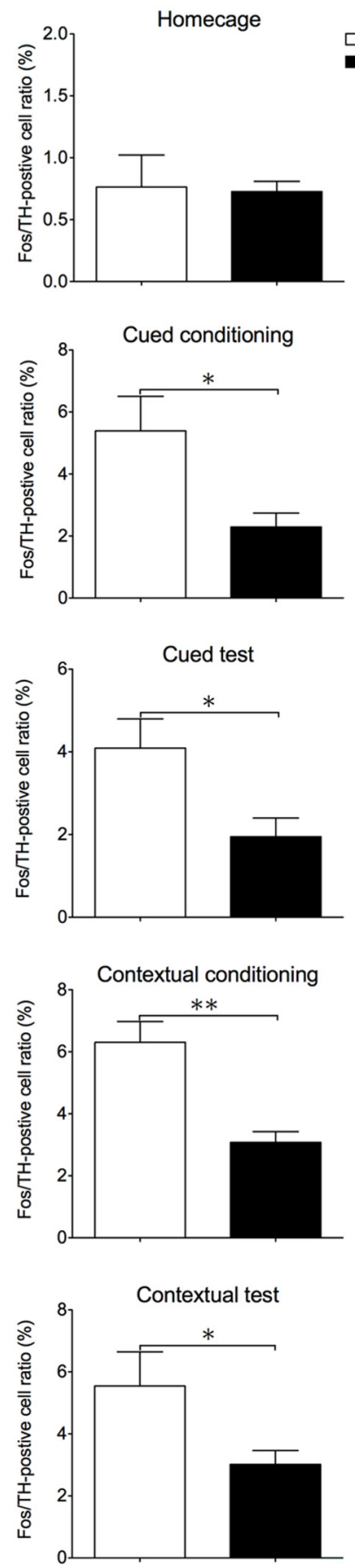

Figure 3. Fos expression in NA neurons in the $L C$ after fear conditioning was decreased in $0 \times 1 r^{-1-}$ mice. Representative images of dual-labeling immunofluorescent study of Fos and TH are shown in the two left columns $(\boldsymbol{B}-\boldsymbol{F})$. Immunoreactivity for Fos is shown in red and for TH is shown in green. Quantification of the number of double-positive neurons is shown on the right $(\boldsymbol{B}-\boldsymbol{F})$. Data are shown as mean \pm SEM. $\boldsymbol{A}$, Schematic representation of experimental design. $\boldsymbol{B}$, Number of Fos/TH double-positive cells in $0 \times 1 r^{-/-}$mice in their home cages is similar to that in wild-type (WT) mice. C, After cued fear conditioning, the number of double-positive cells was significantly lower in $0 \times 1 r^{-1-}$ mice than in WT mice $\left(n=5,0 \times 1 r^{-/-} ; n=6\right)$. $D$, Number of double-positive neurons was significantly lower in $0 \times 1 r^{-1-}$ mice after cued test (WT; $\left.n=6,0 \times 1 r^{-1-} ; n=7\right)$. $\boldsymbol{E}$, Number of double-positive neurons was significantly lower in $0 \times 1 r^{-1-}$ mice after contextual conditioning (WT; $\left.n=4,0 \times 1 r^{-1-} ; n=4\right)$. $\boldsymbol{F}$, Number of double-positive neurons was significantly lower in $0 \times 1 r^{-/-}$mice after contextual test (WT; $n=9,0 \times 1 r^{-/-} ; n=9$ ). Scale bars, $30 \mu \mathrm{m} .{ }^{*} p<0.05$ and $^{* *} p<0.01$.

wild-type mice, especially in the presence of CS, with a longer freezing time compared with that in the KO-ChR2 group $(t=2.243, p=0.0430$; Fig. $4 E)$. These observations suggest that OX1R in LC-NA neurons does not play a major role in the emergence of fear-related behavior in unconditioned situations, but is likely to play an important role in consolidation, retrieval, and presentation of cuedependent fear memory (Fig. $4 E$ ).

AAV-mediated expression of OX1R in LC-NA neurons in wild-type mice (WTOX1R) showed no difference in freezing response in both cued and contextual fear conditioning and testing compared with wild-type mice (data not shown; Fig. $4 E$ ).

Conversely, in the contextual fearconditioning test, we did not find any difference between the KO-OX1R and KO-ChR2 groups during both the conditioning and test periods $\left(F_{(1,12)}=0.02\right.$; $p=0.8964 ; F_{(1,12)}=0.03 ; p=0.8711$, respectively; Fig. $4 F-H$ ). The KO-OX1R group showed significantly less freezing behavior during both the conditioning and test periods compared with wild-type $\left(F_{(1,22)}=3.97 ; p=0.0325 ; F_{(1,22)}=4.73\right.$; $p=0.0407$, respectively). These results suggest that restoration of OX1R expression in the LC is not sufficient to rescue the formation of fear memory of contextual information. Restoration of OX1R expression in LC-NA neurons also did not affect freezing behavior during the contextual conditioning session, suggesting that the mechanisms of emergence of a behavioral response to unconditioned threats do not depend on OX1R in LC-NA neurons, but rather involve OX1R in other brain region(s).

\section{OX1R in LC-NA neurons plays an} important role in activation of the amygdala during fearful situations To investigate whether OX1R in LC-NA neurons is involved in activation of the amygdala in fearful situations, we tracked the level of zif268 (Egr-1) protein expression in the LA. We analyzed zif268 expression in mice after cued or contextual fear tests. No difference was found in the level of zif268 in the LA between genotypes in a naive condition (WT; $n=5, O x 1 r^{-/-}$; $n=5, p=0.1980$; Fig. $5 B$ ). After cued or contextual tests, $O x 1 r^{-1-}$ mice showed fewer zif268-positive cells in the LA after cued test (Fig. 5C) (WT; $n=4, O \times 1 r^{-1-}$; $n=5, p=0.0068)$. We also observed a similar tendency in the contextual test, but the difference did not reach significance (Fig. 5D) (WT; $n=5, O \times 1 r^{-1-} ; n=$ $5, p=0.0684)$. 


\section{AAV $_{2}$-PRSX8-1R-EYFP TTR PRS X8 OX1R-EYFP WPRE PA ITR \\ AAV $_{2}-$ PRS 8 8-ChR2-EYFP ITR PRS 88 ChR2-EYFP WPRE PA ITR}
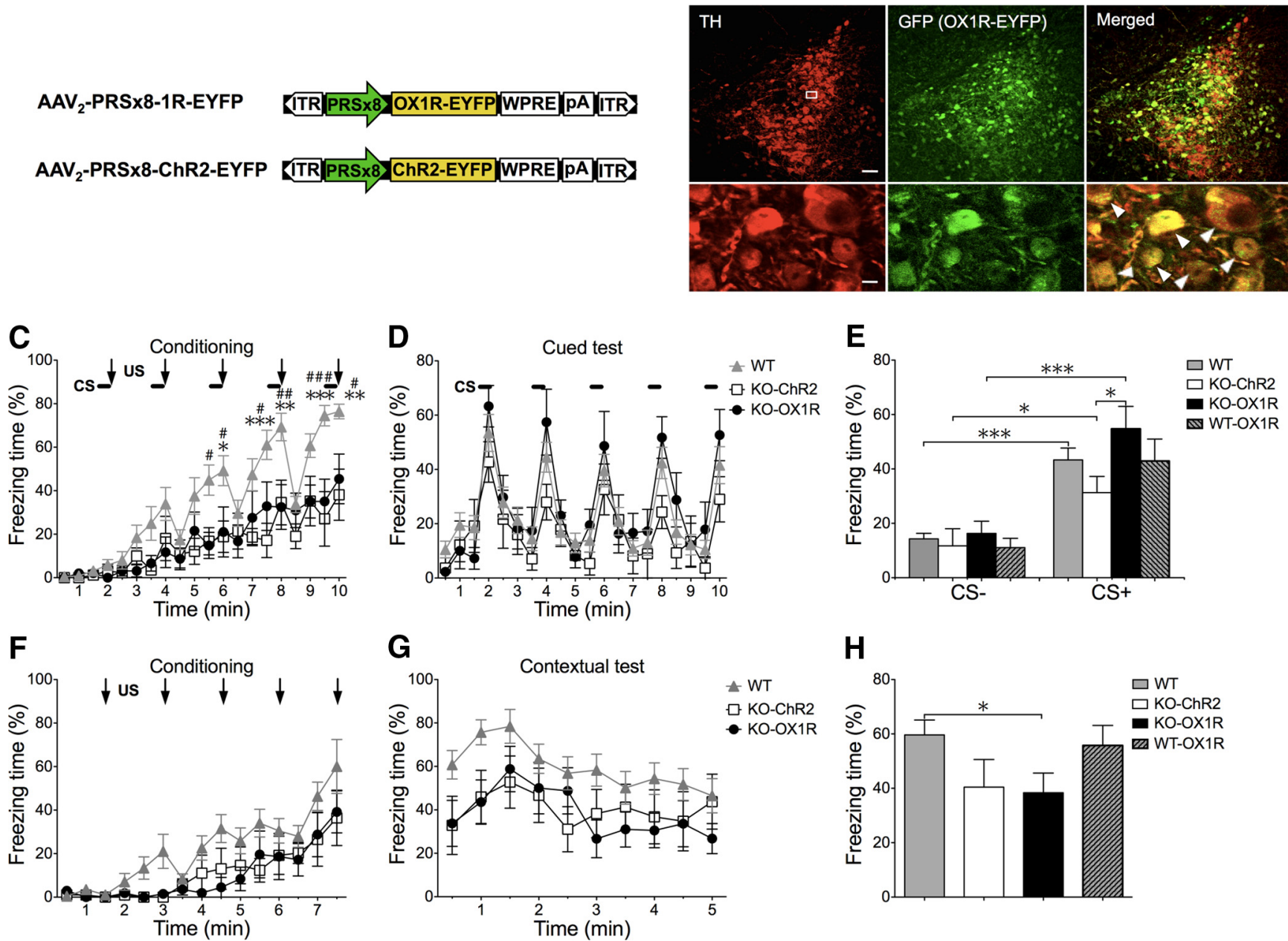

Figure 4. OX1R in the LC is involved in consolidation of cued fear memory. An AAV with LC-NA neuron-specific promoter carrying ChR2 or OX1R each fused to EYFP was injected bilaterally into the $\mathrm{LC}$ in $0 \times 1 r^{-/-}$mice to examine the effects of their expression on freezing behavior. We used ChR2 injection for the control group. Then, we performed the cued and contextual fear-conditioning test as shown in Figures 1 and 2, and examined whether LC-NA neuron-specific restoration of $0 X 1 R$ expression in the LC could rescue the fear response. $A$, Constructs of recombinant AAV vectors carrying OX1R for rescued group or ChR2 for control group. B, A representative image of brain sections of $0 \times 1 r^{-1-}$ mice prepared from AAV-OX1R-EYFP injection group after behavioral analysis labeled with TH and GFP. Immunoreactivity for TH is shown in red, while that of GFP (OX1R-EYFP) is shown in green. Arrows show examples of colocalization (yellow in merged images). Scale bars: $50 \mu \mathrm{m}$ (top), $10 \mu \mathrm{m}$ (bottom). C, Freezing time of Ox1r ${ }^{-1-}$ mice with ChR2 expression in LC-NA neurons (KO-ChR2, $n=7$ ) and with OX1R expression in LC-NA neurons (KO-0X1R, $\left.n=8\right)$ during the cued fear-conditioning period. ${ }^{*} p<0.05,{ }^{* *} p<0.01,{ }^{* * *} p<0.001$, wild-type (WT) vs K0-0X1R, \#p $<0.05$, \#\#p $<0.01$, \#\#\#p $<0.001$, and WT vs K0-ChR2. D, Effects of OX1R injection on freezing time during test period of cued fear conditioning. $\boldsymbol{E}$, Graphic representation of results in $\boldsymbol{D}$. OX1R injection significantly increased freezing behavior of $0 \times 1 r^{-1}$ mice (K0-0X1R) specifically in the presence of auditory $C S$, but did not change it in the absence of $C S$. We also expressed OX1R in NA-LC neurons in WT mice (WT-0X1R, $n=7)$. This group did not show any difference compared with WT. $\boldsymbol{F}$, Freezing time of each group during conditioning session of the contextual fear-conditioning test. There was no significant difference between K0-ChR2 $(n=7)$ and K0-0X1R $(n=7)$ groups during the conditioning period. $\mathbf{G}$, Effect of restored expression of $0 X 1 \mathrm{R}$ in $\mathrm{LC}$ on freezing behavior during the test period of contextual fear conditioning compared with the control group. $\boldsymbol{H}$, Graphic representation of the results in $\mathbf{G}$. We also expressed OX1R in NA-LC neurons in WT mice (WT-0X1R, $n=7$ ). Data are shown as mean \pm SEM ${ }^{*} p<0.05$, ${ }^{* *} p<0.01$, and ${ }^{* * *} p<0.001$.

Furthermore, rescue of OX1R in LC-NA neurons in Oxlr ${ }^{-1-}$ mice increased Fos expression in the LC (KO-ChR2; $n=5$, KOOX1R; $n=5, t=2.744, p=0.0253$ ) and zif268 protein in the LA after cued testing, to levels comparable to those in wild-type mice $(\mathrm{KO}-\mathrm{ChR} 2 ; n=5, \mathrm{KO}-\mathrm{OX} 1 \mathrm{R} ; n=6, t=2.861, p=0.0187$; Fig. $6 B, C)$. In contrast, ChR2 expression did not show an effect. OX1R rescue in LC-NA neurons did not normalize zif268 protein expression after the contextual test $(n=5$ each, $t=0.5429, p=$ 0.6020 ), although it increased the number of Fos-positive TH neurons in the LC (KO-ChR $2 ; n=5, \mathrm{KO}-\mathrm{OX} 1 \mathrm{R} ; n=4, t=3.512$, $p=0.0098$; Fig. $6 D, E)$. These observations suggest that OX1R in LC-NA neurons plays an important role in activation of the amygdala in response to an explicit cue, presumably through NA projections to the amygdala. However, this system is not sufficient to lead to amygdala activation in response to emotionally relevant contextual information.

\section{Discussion}

OX1R is abundantly expressed in LC-NA neurons. Although there is one report suggesting that OX1R signaling is involved in depression-like behavior (Scott et al., 2011), physiological roles of OX1R in the LC are hardly known.

Several studies have implicated LC-NA neurons in establishing fear memory. For instance, activity of LC-NA neurons increased after a fear-conditioning test (Ishida et al., 2002). NA release in the LA increased with presentation of stressful stimuli (Galvez et al., 1996). Involvement of the NA system in fear and anxiety has also been shown clinically, because $\beta$-adrenergic blockade has been shown to be effective for treating patients with post-traumatic stress disorder (Vaiva et al., 2003).

Clinical investigation suggests that human narcolepsy-cataplexy, a sleep-wake disorder caused by a specific loss of hypotha- 
A

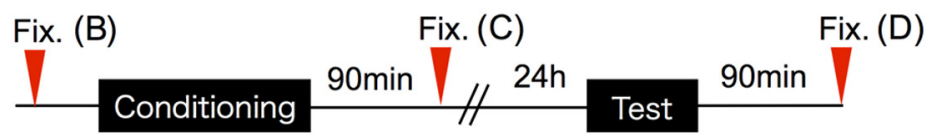

B
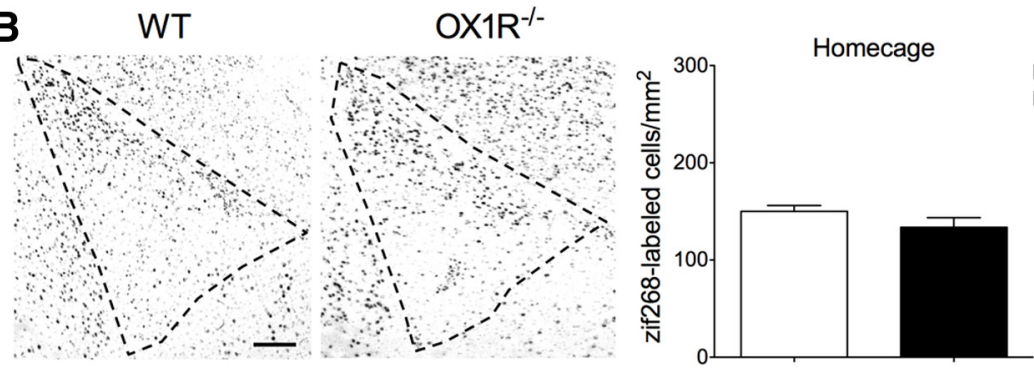

C
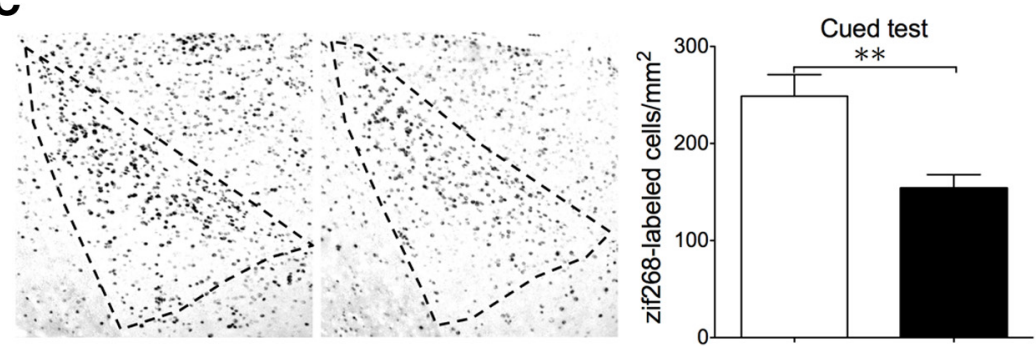

D
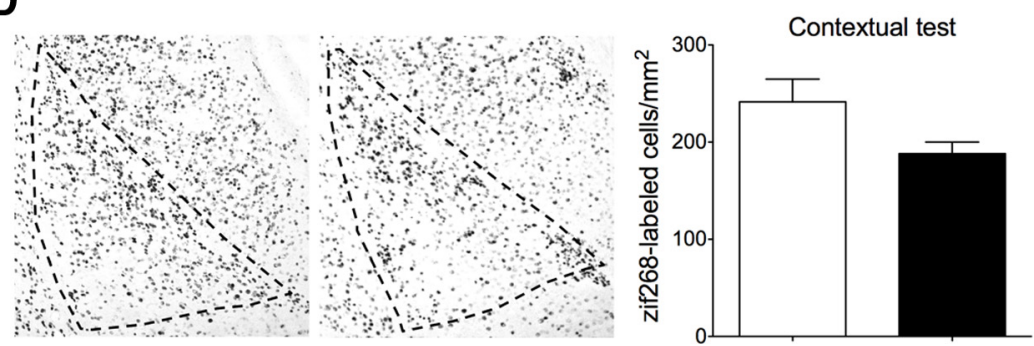

Figure 5. Zif 268 expression in the $L A$ after cued fear test was lower in $0 \times 1 r^{-1-}$ mice. Immunostaining of zif268 in the LA. $A$, Schematic representation of experimental design. $\boldsymbol{B}$, A representative image of zif268-positive cells in the LA of wild-type (WT; left) and $0 \times 1 r^{-\prime-}$ mice (right). There was no significant difference between genotypes. $C$, Number of zif268-positive cells after cued fear test was significantly lower in $0 \times 1 r^{-1-}$ mice compared with WT. ${ }^{* *} p<0.01$. D, Number of zif268-positive cells in the LA of $0 \times 1 r^{-1-}$ mice and WT. Scale bar, $30 \mu \mathrm{m}$. Data are shown as mean \pm SEM.

lamic orexin, is associated with reduced amygdala activity during aversive conditioning (Ponz et al., 2010), suggesting that the orexin system is involved in the regulation of amygdala function. Recent observations also showed that activation of orexin neurons is necessary for developing a panic-prone state in an animal model, and either silencing the hypothalamic orexin gene with RNA interference or a systemic OX1R antagonist blocks the panic responses. Human subjects with panic anxiety have elevated level of orexin A in the CSF compared with subjects without panic anxiety (Johnson et al., 2010). These findings suggest that OX1R in the LC is involved in anxiety and fear. Supporting this hypothesis, a recent paper suggested that orexin receptors contribute to fear-conditioned startle reactions in the rat, using a dual orexin receptor antagonist, almorexant (Steiner et al., 2012).

Considering these observations, we hypothesized that orexin neurons regulate LC-NA neurons in fearful condition, and this pathway might play a role in establishing fear memory. To evaluate this hypothesis, we examined $O x 1 r^{-/-}$mice in cued and contextual fearconditioning tests. $O \times 1 r^{-1-}$ mice displayed significant impairment of evoked freezing behavior, that is, behavioral expression of fear, in response to cued and contextual fear stimuli, whereas $O \times 2 r^{-1-}$ mice showed reduced freezing response to a contextual stimulus only (Figs. 1, 2).

Contrary to our initial hypothesis that OX1R in the LC might play an important role in acquisition and consolidation of fear-related memories, freezing time was already substantially decreased in $O x 1 r^{-/-}$ mice in the conditioning period of both cued and contextual fear-conditioning paradigms (Figs. 1B, 2B). This suggests that OX1R signaling is involved in presentation of freezing behavior itself. However, while wild-type mice showed increased expression of fear in the test compared with conditioning session, the $O \times 1 r^{-/-}$mice showed a smaller increase across both phases (Fig. 2B,C). This suggests that $O x 1 r^{-/-}$mice have deficits in the fear memory consolidation process. Also, Fos expression after the test sessions was lower in $O x 1 r^{-1-}$ mice (Fig. 3D,F). These findings imply two possibilities: (1) OX1R may play an important role in expression of fear itself or (2) OX1R may play roles in both expression of fear and formation of fear-related memory.

To test the latter possibility, we next examined the contribution of OX1R in LC-NA neurons by expressing OX1R specifically in LC-NA neurons in Oxlr ${ }^{-1-}$ mice. We specifically expressed OX1R in both sides of the LC in Ox1r $r^{-/-}$mice by AAV-mediated gene transfer. We found no difference in freezing behavior in the OX1Rrestored and control (ChR2-expressed) groups in the conditioning sessions in both cued and contextual fear conditioning (Fig. $4 C, F)$. This suggests that the mechanisms of behavioral responses to unconditioned threats evoked by sensory cues do not depend on OX1R in LC-NA neurons, but rather involve OX1R in other brain regions. LeDoux (2012) suggested that the fear response to electric shock involves sensory transmission to the LA through circuitry involving the accessory basal amygdala, ventromedial hypothalamus, premammillary nucleus of the hypothalamus, and dorsal periaqueductal gray. The LC is not involved in this circuit, which is consistent with our observation that restoration of OX1R in the LC did not affect freezing in the conditioning period.

In stark contrast, we found that restoration of OX1R in LC-NA neurons significantly increased freezing time in the test session of the cued fear-conditioning paradigm compared with that in the ChR2-expressing group (Fig. 4D,E). Furthermore, we found a group of mice in which virus injection was not successful (in which expression of OX1R-GFP in LC-NA neurons was $<10 \%$ ), which did not show any significant difference compared with the ChR2-injected group in the cued test (16.77 \pm 5.24 and $28.77 \pm 9.61 \%$ for failed injection group and ChR2 injection group, $n=9$ and 7 , respectively, $t=165, p=0.2636$ ).

These findings suggest that OX1R in LC-NA neurons plays a prominent role in the consolidation of cued fear memory. Furthermore, we found obvious differences in the number of Fospositive TH neurons in the LC after the cued or contextual 
training sessions (Fig. 3). This further supports our hypothesis that activation of LC-NA neurons through OX1R might play an important role in the consolidation of fear memory after training. These results are consistent with a former study showing that the reconsolidation process of auditory cue-conditioned fear requires NA signaling via the $\beta$-adrenergic receptor (Dębiec et al., 2011) and implies that this mechanism requires orexinergic modulation through OX1R.

We also found that the sole expression of OX1R in LC-NA neurons did not restore freezing behavior in the contextual fear test (Fig. $4 F, G$ ), suggesting that OX1R-mediated activation of LC-NA neurons is not sufficient to restore the establishment of contextual fear memory. This hypothesis is further supported by our observation that rescue of OX1R in LC-NA neurons in Ox1r ${ }^{-1-}$ mice normalized activation of the LA after the cued test, but not after the contextual test (Fig. 6). Although rescue of OX1R in LC-NA neurons increased the activation of LC-NA neurons after the context test, it was not sufficient to rescue amygdala activation. This suggests that other OX1Rmediated pathways might play significant roles in the activation of the amygdala in a fearful context.

Our present study suggests an important role of OX1R in cued fear memory. Previously, LeDoux et al. (1988) excluded a role of the lateral hypothalamus in cued fear learning, based on lesion experiments in rats. In contrast, a study showed that an orexin-specific neurotoxin-induced lesion of the perifornical hypothalamus led to impairment of the behavioral response in contextual fear conditioning, suggesting that orexin neurons play an important role in this function (Furlong and Carrive, 2007). These differences might stem from differences in animal species, experimental paradigm, and procedure to disrupt the lateral hypothalamus. Our present data clearly suggest that the orexin system may modulate the formation of fear memory through activation of LC-NA neurons.

Recently, the effects of almorexant, a dual orexin receptor antagonist, on contextual fear memory were reported. Almorexant did not reduce freezing, and nor did it significantly reduce the associated USVs in rats (Furlong et al., 2009). This suggests that acute blockade of orexin receptors does not affect contextual fear memory. The difference between this report and our present findings that both $O \times 1 r^{-1-}$ and $O \times 2 r^{-1-}$ mice showed reduced freezing in the contextual fear test might stem from the species difference and/or methodological difference, i.e., acute pharmacological blockade versus genetic modification and/or monitoring USVs versus freezing responses. However, in another report, almorexant was reported to decrease the fear response to cued fear to a light CS (Steiner et al.,
A

B $\mathrm{KO}-\mathrm{ChR} 2$
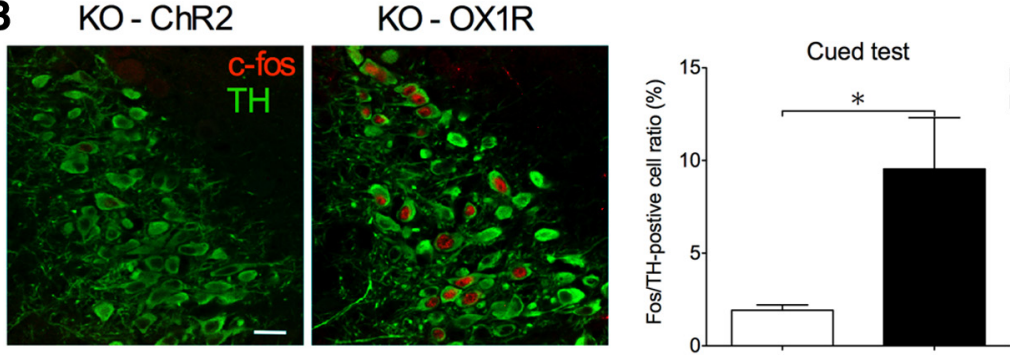

C
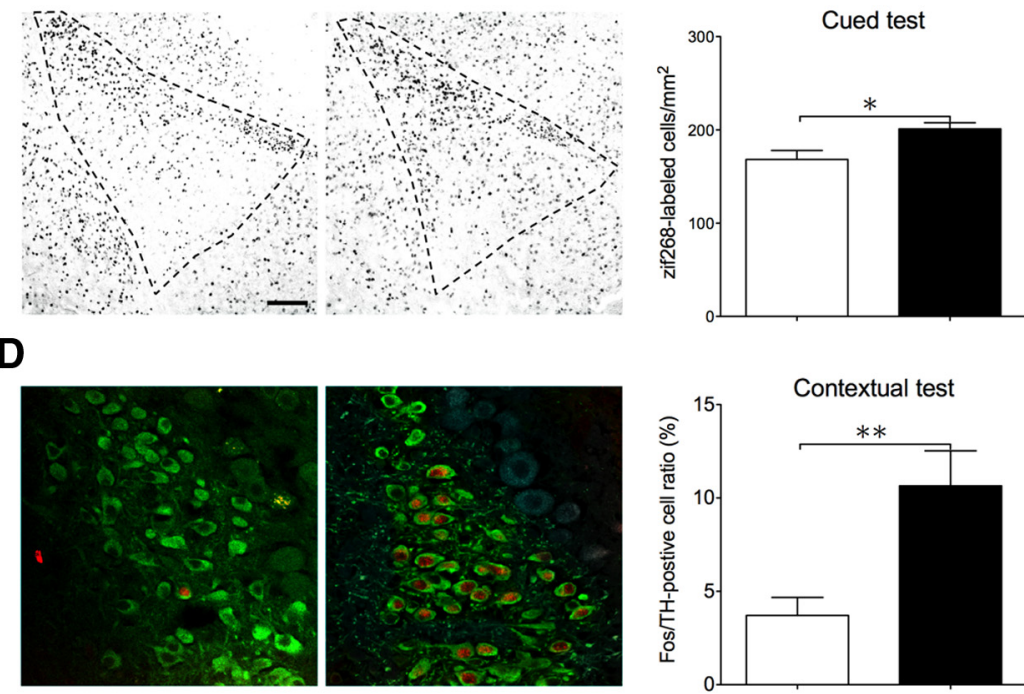

$\mathbf{E}$
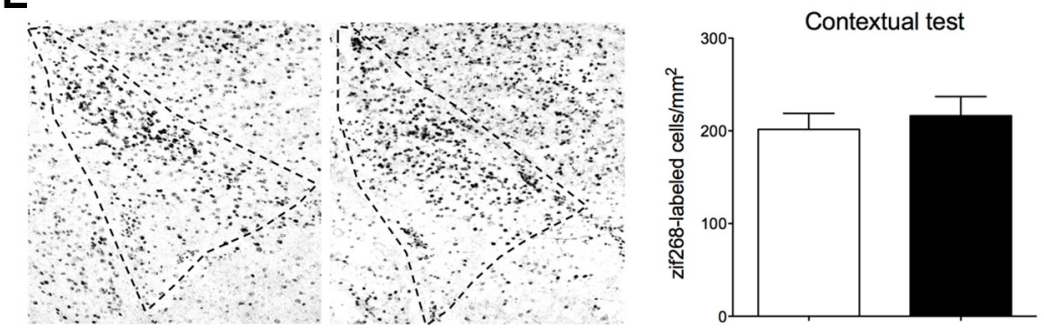

Figure 6. NA input from $L C$ through $O X 1 R$ plays an important role in activation of $L A$. $A$, Schematic representation of experimental design. $\boldsymbol{B}-\boldsymbol{E}$, Immunostaining of zif268 in the $L A(\boldsymbol{C}, \boldsymbol{E})$ and Fos/TH double-positive cells in the $L C(\boldsymbol{B}, \boldsymbol{D})$ was examined after cued and contextual fear test in $\mathrm{Xx}_{1 r^{-\prime}}{ }^{-}$mice with AAV-mediated expression of OX1R (KO-1R) or ChR2 (KO-ChR2) in LC-NA cells. $\boldsymbol{B}-\boldsymbol{E}$, Representative images showing the $\mathrm{LC}(\boldsymbol{B}, \boldsymbol{D})$ or $\mathrm{LA}(\boldsymbol{C}, \boldsymbol{E})$ of ChR2-injected (left) and OX1R-injected (center) $0 \times 1 r^{-1-}$ mice. $\boldsymbol{B}-\boldsymbol{E}$, Right, Shows quantification of positive cells. ${ }^{*} p<0.05$. Scale bars: $\boldsymbol{B}, \boldsymbol{D}, 50 \mu \mathrm{m} ; \boldsymbol{C}, \boldsymbol{E}, 30 \mu \mathrm{m}$. Data are shown as mean $\pm \mathrm{SEM}$.

2012). Consistently, our present study also suggests that OX1R in the LC plays an important role in cued fear conditioning. This result helps explain the dissociation between the effects of orexin receptor blockade on contextual and explicit cued fear. Both acute pharmacological blockade of OX1R and genetic disruption of the Oxlr gene impaired freezing in response to cued fear. Likewise, focal expression of OX1R in LC-NA neurons increased freezing behavior to a level comparable to that of wild-type in cued fear testing, but did not affect freezing in response to contextual fear. These results are consistent with the reports that showed lack of an effect of almorexant on contextual fear conditioning versus potent effects on fear conditioning to CS (Furlong et al., 2009; Steiner et al., 2012). 
We found a prominent role of OX1R in cued fear conditioning, while most other peptides have been shown to be implicated in contextual fear conditioning and thus may play a role in contextual cue processing rather than in processing of fear conditioning per se. Our results also suggest that OX1R expressed in several regions of the brain plays different roles in fear-related behavior and memory through independent mechanisms. Especially, the orexin system is involved in the consolidation of cue-dependent fear memory via OX1R expressed in NA neurons in the LC. In addition, OX2R may also be involved in establishing contextual fear memory, suggesting a further complex mechanism involving the hippocampus or other OX2R-expressing regions. In conclusion, our findings show that the mechanism of establishing fear memory critically involves the orexin system. These findings might contribute to understanding of the complex neural mechanism in establishing fear memory.

\section{References}

Bailey CH, Giustetto M, Huang YY, Hawkins RD, Kandel ER (2000) Is heterosynaptic modulation essential for stabilizing Hebbian plasticity and memory? Nat Rev Neurosci 1:11-20. CrossRef Medline

Bush DE, Caparosa EM, Gekker A, Ledoux J (2010) Beta-adrenergic receptors in the lateral nucleus of the amygdala contribute to the acquisition but not the consolidation of auditory fear conditioning. Front Behav Neurosci 4:154. Medline

Chen FJ, Sara SJ (2007) Locus coeruleus activation by foot shock or electrical stimulation inhibits amygdala neurons. Neuroscience 144:472-481. CrossRef Medline

Date Y, Ueta Y, Yamashita H, Yamaguchi H, Matsukura S, Kangawa K, Sakurai T, Yanagisawa M, Nakazato M (1999) Orexins, orexigenic hypothalamic peptides, interact with autonomic, neuroendocrine and neuroregulatory systems. Proc Natl Acad Sci U S A 96:748-753. CrossRef Medline

Dêbiec J, Bush DE, LeDoux JE (2011) Noradrenergic enhancement of reconsolidation in the amygdala impairs extinction of conditioned fear in rats-a possible mechanism for the persistence of traumatic memories in PTSD. Depress Anxiety 28:186-193. CrossRef Medline

Díaz-Mataix L, Ruiz Martinez RC, Schafe GE, LeDoux JE, Doyère V (2013) Detection of a temporal error triggers reconsolidation of amygdaladependent memories. Curr Biol 23:467-472. CrossRef Medline

Funato H, Tsai AL, Willie JT, Kisanuki Y, Williams SC, Sakurai T, Yanagisawa M (2009) Enhanced orexin receptor-2 signaling prevents diet-induced obesity and improves leptin sensitivity. Cell Metab 9:64-76. CrossRef Medline

Furlong T, Carrive P (2007) Neurotoxic lesions centered on the perifornical hypothalamus abolish the cardiovascular and behavioral responses of conditioned fear to context but not of restraint. Brain Res 1128:107-119. CrossRef Medline

Furlong TM, Vianna DM, Liu L, Carrive P (2009) Hypocretin/orexin contributes to the expression of some but not all forms of stress and arousal. Eur J Neurosci 30:1603-1614. CrossRef Medline

Galvez R, Mesches MH, McGaugh JL (1996) Norepinephrine release in the amygdala in response to footshock stimulation. Neurobiol Learn Mem 66:253-257. CrossRef Medline

Hondo M, Nagai K, Ohno K, Kisanuki Y, Willie JT, Watanabe T, Yanagisawa M, Sakurai T (2010) Histamine-1 receptor is not required as a downstream effector of orexin-2 receptor in maintenance of basal sleep/wake states. Acta Physiol 198:287-294. CrossRef Medline

Hwang DY, Carlezon WA Jr, Isacson O, Kim KS (2001) A high-efficiency synthetic promoter that drives transgene expression selectively in noradrenergic neurons. Hum Gene Ther 12:1731-1740. CrossRef Medline

Ishida Y, Hashiguchi H, Takeda R, Ishizuka Y, Mitsuyama Y, Kannan H, Nishimori T, Nakahara D (2002) Conditioned-fear stress increases Fos expression in monoaminergic and GABAergic neurons of the locus coeruleus and dorsal raphe nuclei. Synapse 45:46-51. CrossRef Medline

Johnson PL, Truitt W, Fitz SD, Minick PE, Dietrich A, Sanghani S, TräskmanBendz L, Goddard AW, Brundin L, Shekhar A (2010) A key role for orexin in panic anxiety. Nat Med 16:111-115. CrossRef Medline

LeDoux J (2012) Rethinking the emotional brain. Neuron 73:653-676. CrossRef Medline

LeDoux JE, Iwata J, Cicchetti P, Reis DJ (1988) Different projections of the central amygdaloid nucleus mediate autonomic and behavioral correlates of conditioned fear. J Neurosci 8:2517-2529. Medline
Marcus JN, Aschkenasi CJ, Lee CE, Chemelli RM, Saper CB, Yanagisawa M, Elmquist JK (2001) Differential expression of orexin receptors 1 and 2 in the rat brain. J Comp Neurol 435:6-25. CrossRef Medline

McGaugh JL, Roozendaal B (2002) Role of adrenal stress hormones in forming lasting memories in the brain. Curr Opin Neurobiol 12:205-210. CrossRef Medline

Mieda M, Hasegawa E, Kisanuki YY, Sinton CM, Yanagisawa M, Sakurai T (2011) Differential roles of orexin receptor-1 and -2 in the regulation of non-REM and REM sleep. J Neurosci 31:6518-6526. CrossRef Medline

Miyakawa T, Leiter LM, Gerber DJ, Gainetdinov RR, Sotnikova TD, Zeng H, Caron MG, Tonegawa S (2003) Conditional calcineurin knockout mice exhibit multiple abnormal behaviors related to schizophrenia. Proc Natl Acad Sci U S A 100:8987-8992. CrossRef Medline

Nambu T, Sakurai T, Mizukami K, Hosoya Y, Yanagisawa M, Goto K (1999) Distribution of orexin neurons in the adult rat brain. Brain Res 827:243260. CrossRef Medline

Peyron C, Faraco J, Rogers W, Ripley B, Overeem S, Charnay Y, Nevsimalova S, Aldrich M, Reynolds D, Albin R, Li R, Hungs M, Pedrazzoli M, Padigaru M, Kucherlapati M, Fan J, Maki R, Lammers GJ, Bouras C, Kucherlapati R, et al. (2000) A mutation in a case of early onset narcolepsy and a generalized absence of hypocretin peptides in human narcoleptic brains. Nat Med 6:991-997. CrossRef Medline

Peyron C, Tighe DK, van den Pol AN, de Lecea L, Heller HC, Sutcliffe JG, Kilduff TS (1998) Neurons containing hypocretin (orexin) project to multiple neuronal systems. J Neurosci 18:9996-10015. Medline

Ponz A, Khatami R, Poryazova R, Werth E, Boesiger P, Schwartz S, Bassetti CL (2010) Reduced amygdala activity during aversive conditioning in human narcolepsy. Ann Neurol 67:394-398. Medline

Sakurai T (2007) The neural circuit of orexin (hypocretin): maintaining sleep and wakefulness. Nat Rev Neurosci 8:171-181. CrossRef Medline

Sakurai T, Amemiya A, Ishii M, Matsuzaki I, Chemelli RM, Tanaka H, Williams SC, Richardson JA, Kozlowski GP, Wilson S, Arch JR, Buckingham RE, Haynes AC, Carr SA, Annan RS, McNulty DE, Liu WS, Terrett JA, Elshourbagy NA, Bergsma DJ, et al. (1998) Orexins and orexin receptors: a family of hypothalamic neuropeptides and $\mathrm{G}$ protein-coupled receptors that regulate feeding behavior. Cell 92:573-585. CrossRef Medline

Sakurai T, Mieda M (2011) Connectomics of orexin-producing neurons: interface of systems of emotion, energy homeostasis and arousal. Trends Pharmacol Sci 32:451-462. CrossRef Medline

Sakurai T, Nagata R, Yamanaka A, Kawamura H, Tsujino N, Muraki Y, Kageyama H, Kunita S, Takahashi S, Goto K, Koyama Y, Shioda S, Yanagisawa M (2005) Input of orexin/hypocretin neurons revealed by a genetically encoded tracer in mice. Neuron 46:297-308. CrossRef Medline

Sasaki K, Suzuki M, Mieda M, Tsujino N, Roth B, Sakurai T (2011) Pharmacogenetic modulation of orexin neurons alters sleep/wakefulness states in mice. PLoS One 6:e20360. CrossRef Medline

Scott MM, Marcus JN, Pettersen A, Birnbaum SG, Mochizuki T, Scammell TE, Nestler EJ, Elmquist JK, Lutter M (2011) Hcrtrl and 2 signaling differentially regulates depression-like behaviors. Behav Brain Res 222:289-294. CrossRef Medline

Steiner MA, Lecourt H, Jenck F (2012) The brain orexin system and almorexant in fear-conditioned startle reactions in the rat. Psychopharmacology 223:465-475. CrossRef Medline

Vaiva G, Ducrocq F, Jezequel K, Averland B, Lestavel P, Brunet A, Marmar CR (2003) Immediate treatment with propranolol decreases posttraumatic stress disorder two months after trauma. Biol Psychiatry 54:947-949. CrossRef Medline

van den Pol AN, Ghosh PK, Liu RJ, Li Y, Aghajanian GK, Gao XB (2002) Hypocretin (orexin) enhances neuron activity and cell synchrony in developing mouse GFP-expressing locus coeruleus. J Physiol 541:169-185. CrossRef Medline

Willie JT, Chemelli RM, Sinton CM, Tokita S, Williams SC, Kisanuki YY, Marcus JN, Lee C, Elmquist JK, Kohlmeier KA, Leonard CS, Richardson JA, Hammer RE, Yanagisawa M (2003) Distinct narcolepsy syndromes in orexin receptor-2 and orexin null mice: molecular genetic dissection of non-REM and REM sleep regulatory processes. Neuron 38:715-730. CrossRef Medline

Winsky-Sommerer R, Yamanaka A, Diano S, Borok E, Roberts AJ, Sakurai T, Kilduff TS, Horvath TL, de Lecea L (2004) Interaction between the corticotropin-releasing factor system and hypocretins (orexins): a novel circuit mediating stress response. J Neurosci 24:11439-11448. CrossRef Medline 
Yoshida K, McCormack S, España RA, Crocker A, Scammell TE (2006) Afferents to the orexin neurons of the rat brain. J Comp Neurol 494:845-861. CrossRef Medline

Zhong L, Li B, Mah CS, Govindasamy L, Agbandje-McKenna M, Cooper M, Herzog RW, Zolotukhin I, Warrington KH Jr, Weigel-Van Aken KA,
Hobbs JA, Zolotukhin S, Muzyczka N, Srivastava A (2008) Next generation of adeno-associated virus 2 vectors: point mutations in tyrosines lead to high-efficiency transduction at lower doses. Proc Natl Acad Sci U S A 105:7827-7832. CrossRef Medline 